2010-07

\title{
Determinants of agricultural land rental market transactions in Bangladesh
}

\author{
Rahman, Sanzidur
}

http://hdl.handle.net/10026.1/4015

10.1016/j.landusepol.2009.12.009

Land Use Policy

Elsevier BV

All content in PEARL is protected by copyright law. Author manuscripts are made available in accordance with publisher policies. Please cite only the published version using the details provided on the item record or document. In the absence of an open licence (e.g. Creative Commons), permissions for further reuse of content should be sought from the publisher or author. 


\title{
Determinants of Agricultural Land Rental Market Transactions in
}

\section{BANGLADESH}

\section{SANZIDUR RAHMAN}

\begin{abstract}
Land rental market transactions have been the norm in land scarce rural Bangladesh mainly due to the inadequacies of the governmental land distribution system to meet the growing demand for land and to correct imbalances in factor proportions at the farm level. The present study jointly determines the socio-economic factors underlying decision to rent-in land and/or rent-out land by the Bangladeshi farmers in the land rental market using a bivariate Tobit model. The model diagnostic reveals that the decisions to rent-in and/or rentout land is significantly correlated, implying that univariate analysis of such decisions are biased, thereby, justifying the use of a bivariate approach. Results reveal that a number of socio-economic factors affect farmers' participation in the land rental market and work in opposite directions regarding the decision to rent-in or rent-out land. The likelihood of rentingin land is higher for farmers with inadequate cultivable land but with higher levels of livestock and other farm capital asset ownership, and also for those located in areas with developed infrastructure and fertile soils. On the other hand, the likelihood of renting-out land is higher among farmers with higher levels of cultivable land but inadequate farm capital and livestock resources, higher levels of education, less subsistence pressure, and poor extension contact. Geography does matter, as the likelihood of land transactions is higher in agriculturally intensive and/or developed regions. Government policy has an important role to play to improve the factor equalisation role of these land rental markets through, for example, investment in education, agricultural extension, rural infrastructure and the livestock sector.
\end{abstract}

JEL Classification: Q15.

Keywords: Land market transactions, bivariate Tobit model, Bangladesh 


\section{Introduction}

Land is the major source of wealth and livelihood in rural Bangladesh, as in other South Asian countries, although the land/person ratio is one of the lowest in the world, estimated at 0.12 ha (FAO, 2001). Bangladesh is also one of the most densely populated nations of the world, with small farms and high levels of land fragmentation. This is further complicated by shrinking availability of land per farm holding due to rising population pressure and closure of the land frontier. Table 1 presents farm dynamics in Bangladesh based on three censuses of agriculture and livestock over the past three decades. The number of farm holdings initially increased rapidly, but then slowed down and there has been a major shift in the composition of farm size groups. Unlike the experience in East Asian countries, such as, Japan and Korea, where farm sizes are getting larger as the number of operational holdings are going down (Niroula and Thapa, 2005), Bangladesh is experiencing rapid decline in farm sizes, coupled with an increase in the number of operational holdings. The average farm size shrank to a level (0.68 ha) at which it is unlikely to sustain livelihoods ${ }^{1}$. The number of small farms increased dramatically at the expense of a reduction in the number of large and medium sized farms. The situation deteriorates further when one considers fragmentation of total land holdings into parcels. Overall, although the number of fragments per holding declined, the average size of fragments has declined in Bangladesh. Nevertheless, the average size of fragments has increased for the large farm size categories, implying that some consolidation is taking place for this size group, perhaps through purchase or simple appropriation from marginal or landless farmers through an exploitative tenurial system.

\section{[Insert Table 1 here]}

\footnotetext{
1 "Small farmers with less than 1 ha of landholdings cannot fulfil their subsistence requirements through agriculture ..." (Niroula and Thapa, 2005).
} 
Since land is in short supply in this densely populated agrarian economy, access to land through rental markets has been an important source to increase the operational farm size to an optimal level. Although, the total number of tenants has increased by $22 \%$ from 3.7 million in 1983/84 to 4.6 million in 1996, the area available for tenancy remained stagnant at 1.9 million ha, implying increased competition in later years (BBS, 1999). Also, 33.8\% of total farmers operated as tenants in 1996 of which, 10.2\% were pure tenants (BBS, 1999). The two common land rental categories in Bangladesh are: (i) share-cropping arrangements, and (ii) cash renting at a fixed predetermined rate. The Land Reform Act of 1984 fixed rents for share-cropping tenants at $33 \%$ of the harvest for the landlords (without input sharing) or $50 \%$ if inputs are shared at a 50\% rate (Akanda et al., 2008).

Although existence of land rental markets has been dominant in Bangladesh, little is known about the key factors that influence the decision to rent-in or rent-out land and the intensity of transactions. In an environment in which factor markets are incomplete, a farm household's initial factor endowments, such as owned land, livestock, family labour, and other socio-economic characteristics are likely to influence its position in the land rental market. This is because, transactions on the land rental markets have a tendency to contribute towards equalizing the size distribution of the farm by: (a) allowing access to land through renting-in by the marginal/landless farmers, and/or (b) promoting a type of equalisation process as large farmers rent-out land and thus transfer land to smaller holdings (Teklu and Lemi, 2004).

Given this backdrop, the aim of this paper is to analyse these land rental markets in Bangladesh by explicitly examining the factors that influence the demand side and/or the supply side of the market using a bivariate Tobit model. The advantage of this bivariate approach, as opposed to the univariate approach commonly seen in the literature (i.e., single equation tobit models of either renting-in land or renting-out land estimated independently), is that it enables us to examine the decision making process of a single farmer who engages with the land rental 
market both as a tenant and as a landlord at the same time. Also, the estimation of a bivariate model is more efficient because it not only nests individual univariate models but also enables us to determine jointness of the decision making process by providing an estimate of the correlation between the error terms of the two univariate models. The paper proceeds as follows: section 2 describes the analytical framework, the study area and the data; section 3 presents the results; and section 4 draws some conclusions and policy implications.

\section{Research Methodology}

\subsection{Analytical framework}

Following Teklu and Lemi (2004), we also postulate that farmers follow sequential decisions; firstly 'whether to participate in the land rental market or not'; and then second, if participating, 'then how much to transact'. In such a case, a censored regression model (i.e., tobit model) is most suitable because it uses all observations, both those which are at the limit, usually zero (e.g., non-participants), and those above the limit (e.g., participants), to estimate a regression line as opposed to other techniques that use observations which are only above the limit value (McDonald and Moffit, 1980). The procedure also captures the latent level of intensity of potential farmers who decide not to participate in the land rental market (Teklu and Lemi, 2004). Let the land transaction function be given by:

$L_{i}^{*}=\beta^{\prime} X_{i}+\mu_{i}$

where $X_{i}$ is the vector of regression, $\beta$ is the vector of parameters to be estimated, and $\mu_{i}$ is the error term. For farmers participating in the land rental market, $L_{i}^{*}$ equals the actual level of transaction $\left(L_{i}\right)$. For those who are not participating in the market, $L_{i}^{*}$ is an index reflecting willingness to participate such that:

$$
\begin{aligned}
L_{i} & =L_{i}^{*} & & \text { if } \beta^{\prime} X_{i}+\mu_{i}>0 \\
& =0 & & \text { if } \beta^{\prime} X_{i}+\mu_{i}<0
\end{aligned}
$$

The advantage of the tobit model as in $\mathrm{Eq}(2)$ is that it captures the decision to participate as 
well as the intensity of transaction in the land rental market, whereas a probit model will provide only information on the decision to participate.

In general, we designate those who rent-out land as the landlords and those who rentin land as the tenants, and therefore, presume that these two groups of farmers are distinctly different with respect to their socio-economic circumstances. As a consequence, most of the literature examining the determinants of land market transactions (e.g., Kung, 2002; Deininger et al., 2003; Teklu and Lemi, 2004; Deininger and Jin, 2005; Swinnen et al., 2006; Vranken and Swinnen, 2006; Masterson, 2007; and Holden et al., 2007) implicitly assumed that the decision to rent-in land and rent-out land are independent of each other, and therefore, estimated separately. However, in this study, we propose that the same farmer can participate in the land rental market, both as a tenant to rent-in land as well as a landlord to rent-out land. This is a plausible assumption, particularly in the case of Bangladesh, where farmers' total holdings are usually composed of several parcels of land scattered over a wide area characterised with varying size, quality and other factors ${ }^{2}$. Therefore, the same farmer can choose to rent-out some of his/her land which is perhaps located far-off from his/her homestead and/or is of poorer quality, and at the same time rent-in land which is perhaps nearer to his/her homestead or other plots. Such an action will allow the farmer to maintain an optimal size of cultivable land although this may now be composed of a combination of rented-in and owned land. In fact, evidence from our sample data suggests that some farmers did rent-in land as well as rent-out land (Table 2). Therefore, in order to incorporate such dynamics in the decision to participate in the land rental market, we postulate a bivariate tobit

\footnotetext{
${ }^{2}$ For example, a survey of rice farmers in Southern region of Bangladesh showed that although the average farm size is small ( $0.78 \mathrm{ha})$, the average level of land fragmentation is 4.4 with a range from a single plot farm to a maximum of a 21 plot farm (Rahman and Rahman, 2009). The Agricultural Census of 1996 also reveals that the average number of fragments per farm is 6 (BBS, 1999).
} 
model:

$L_{1 i}^{*}=\beta^{\prime} X_{1 i}+\mu_{1 i}$

$L_{1 i}=\operatorname{Maximum}\left(L_{1 i}^{*}, 0\right) \quad$ (the usual Tobit specification as in 2$)$.

$L_{2 i}^{*}=\beta^{\prime} X_{2 i}+\mu_{2 i}$

$L_{2 i}=\operatorname{Maximum}\left(L_{2 i}^{*}, 0\right) \quad$ (the usual Tobit specification as in 2$)$.

$\mu_{i i}, \mu_{2 i} \approx N\left[0,0, \sigma_{1}^{2}, \sigma_{2}^{2}, \rho\right]$, cov ariance is $\sigma_{12}=\rho \sigma_{i} \sigma_{2}$.

where $L_{1 i}^{*}$ denotes farmers who participate in the land market to rent-in land; $L_{2 i}^{*}$ denotes farmers who participate in the land market to rent-out land; $\rho$ is the correlation between the error terms $\mu_{1 i}$ and $\mu_{2 i}$. The distributions are independent if and only if $\rho=0$. The full maximum likelihood estimation procedure is utilized using STATA-10 (STATA Corp., 2007) software program.

\subsection{The study area and sample of farmers}

The study is based on farm-level cross section data for the crop year 1996 collected from three agro-ecological regions of Bangladesh. The survey was conducted from February to April 1997. Samples were collected from eight villages of the Jamalpur Sadar sub-district of Jamalpur (representing wet agro-ecology), six villages of the Manirampur sub-district of Jessore (representing dry agro-ecology), and seven villages of the Matlab sub-district of Chandpur (representing wet agro-ecology in an agriculturally advanced area). A multistage random sampling technique was employed to locate the districts, then the Thana (subdistricts), then the villages in each of the three sub-districts, and finally the sample households. A total of 406 households $^{3}$ from these 21 villages were selected. Detailed

\footnotetext{
${ }^{3}$ The sample households were selected based on the information on the total number of households including their land ownership categories, which were obtained from BRAC (a national non-governmental organization). Then a stratified random sampling procedure was applied using a formula from Arkin and Colton (1963) that maximizes the sample size with a 5\% error limit. Farm size categories (large, medium, and small farmers) were used as the strata (for details, see Rahman, 1998).
} 
information on land ownership patterns, crop input-output data and selected socio-economic indicators for individual farm households were collected. The dataset also includes information on the level of infrastructural development and soil fertility, determined from soil samples collected from representative locations in the study villages.

\subsection{The empirical model}

A bivariate tobit model is developed to empirically investigate the socio-economic factors underlying the decision to participate in the land rental market as tenants compared with the decision to participate as landlords in Bangladesh. The choice of variables representing socioeconomic circumstances of the farmer is based on the existing literature dealing with land market transactions, with similar justification therein (e.g., Kung, 2002; Deininger, et al., 2003; Teklu and Lemi, 2004; Tikabo and Holden, 2004; Deininger and Jin, 2005; Swinnen et al., 2006; Vranken and Swinnen, 2006; Holden et al., 2007; and Masterson, 2007). The most common variables used in these studies were: age of the farmer, education, land and non-land resource endowments, irrigation access, and off-farm employment. However, we have also added additional household level and regional level variables that we hypothesise as having an influence on the land market participation decision although not commonly seen in the literature, e.g., access to extension services, level of crop diversification, levels of infrastructural development, soil fertility and income inequality in the study villages.

The dependent variables are the actual amount of land rented-in per capita and actual amount of land rented-out per capita. The socio-economic variables explaining decisions to participate in the land rental markets are: amount of total cultivated land owned, value of farm capital assets, value of livestock asset, highest level of education in the household, farming experience, subsistence pressure, extension contact in the past year, share of nonagricultural income in total income, level of crop diversification ${ }^{4}$, and access to irrigation.

\footnotetext{
${ }^{4}$ A Herfindahl index is used to represent the specialization/diversification variable. Although, this index is
} 
The three village level variables include an index of underdevelopment of infrastructure 5 , a soil fertility index ${ }^{6}$, and a Gini-coefficient of income inequality, along with two dummy variables to account for regional variations (i.e., Comilla and Jamalpur, whereas the effect of Jessore is subsumed in the intercept term). The definition, measure and summary statistics of

mainly used in the marketing industry to analyze market concentration, it has also been used to represent crop diversification and/or concentration (e.g., Llewelyn and Williams, 1996; Bradshaw, 2004; Rahman 2009). The Herfindahl index is represented as: $D V=\sum_{i=1}^{n} P_{i}^{2}$, where $P_{i}$ is the proportion of farm area involved in a particular enterprise. The value of Herfindahl index ranges between 0 and 1 with 0 denoting perfect diversification and 1 denoting perfect specialization.

${ }^{5}$ A composite 'index of underdevelopment of infrastructure' was constructed using the cost of access approach. A total of 13 elements are considered for its construction. These are primary market, secondary market, storage facility, rice mill, paved road, bus stop, bank, union office, agricultural extension office, high school, college, thana (sub-district) headquarters, and post office. A total cost (TC) of access was computed by summing up individual costs $\left(I C_{i}\right)$ of access (i.e., distance $\mathrm{x}$ cost per km). Then, $T C$ was correlated with costs for each element $\left(I C_{i}\right)$ which provided individual correlation coefficients $\left(W_{i}\right)$. The final index (INF) was then calculated by summing up all the ICs (each weighted by its correlation coefficient) and divided by sum of all correlation coefficients (see Ahmed and Hossain, 1990 for further details).

${ }^{6}$ The 'soil fertility index' was constructed from the test results of soil samples collected from the study villages. Ten soil fertility parameters were tested; these are soil $\mathrm{pH}$, available nitrogen, available potassium, available phosphorus, available sulphur, available zinc, soil texture, soil organic matter content, cation exchange capacity of soil, and electrical conductivity of soil (for details of sampling and tests, see Rahman and Parkinson, 2007 and Rahman, 1998). A composite weighted index of soil fertility was constructed using a Likert type scale. First, each of the soil parameters were categorized into 'high', 'medium' or 'low' level following the guideline provided by the Soil Resources Development Institute (SRDI) of Bangladesh, which assigns these categories based on a range of values of each soil parameter required for crop growth (SRDI, 1991). Then, the soil fertility index was constructed by summing up the index of each soil parameter, divided by the total number of parameters used in the computation. 
these variables are provided in Table 3.

Since a priori information is not available on which variables affect the decision to rent-in land and/or rent-out land, we have incorporated the same set of variables in both models, but expect to see differential influences of these socio-economic factors on the decision to participate as tenants and/or landlords in the land rental market. For example, the influence of other non-land assets may affect the decision to rent-in and rent-out differently. While land poor farmers may opt to rent-in land, to arrive at an optimum farm size, large landowners may opt to rent-out surplus land to raise income. The other variables that we expect to have differential influences are: farm capital assets, livestock (a key resource in farming which is largely used as draft power in Bangladesh), level of education in the household, subsistence pressure, and the three village level variables.

\section{Results and discussions}

\subsection{Extent of participation in the land rental market}

Table 2 presents the extent of participation of sampled farmers in the land rental market. A total of four possibilities were considered: (a) non-participants, i.e., farmers who neither rent-in nor rent-out land, (b) tenants or part-tenants, i.e., farmers who rent-in land only, (c) landlords, i.e., farmers who rent-out land only, and (d) mixed role, i.e., farmers who rent-in and rent-out land. Overall, $37 \%$ of the sampled farmers did not participate in the land market (highest $42 \%$ in Jessore), thereby justifying the use of a truncated regression (tobit) model. Also, $38 \%$ of the farmers participated in the land market to rent-in land only (highest $42 \%$ in Comilla characterized by lowest per capital land ownership). The proportion of farmers participating in the land rental market as landlords (i.e., renting-out land only) is almost the same in every region, standing at $21 \%$. Also, $6.3 \%$ of farmers (the overall figure is 4\%) participated in the land-rental market both as landlords as well as tenants in Jamalpur, an intensive agricultural region, thereby, justifying the use of the bivariate approach. 
One of the explanations of non-participation in the land rental market is the transaction cost (Teklu and Lemi, 2004; Tikabo and Holden, 2004) and that transaction cost would drive a wedge between the costs and benefits of tenancy as a landlord and/or as a tenant (Bell and Sussangkarn, 1988). The degree of non-participation in the land rental market is an indication of the fixed transaction costs in the market, since it is highly unlikely that all these non-participating households have optimal levels of all factors (both land and non-land factors). The overall rate of non-participation of our sample farmers in the land rental market is considerably lower than those reported by Tikabo and Holden (2004) for Eritrea, estimated at $46 \%$. This is consistent with expectations, since land scarcity in Bangladesh is far higher than in Eritrea. Also, it may be probable that the implied transaction cost of participating in the land rental market is higher in Eritrea than in Bangladesh.

Although the amount of land rented-in per farm is substantially higher $(0.13$ ha per farm), the amount of land rented-in and rented-out per capita is exactly the same at 0.02 ha with little inter-regional variations. The implication is that the surface rented-out and surface rented-in are almost equal in each region and that the land rental markets serve well in correcting factor proportions at the farm-level. Almost a third of the operational farm size is composed of renting-in land, with little variation across regions, implying that farmers located in different areas face the same constraint of land scarcity. On the other hand, $23 \%$ of cultivated land that is owned is rented-out by farmers.

\section{[Insert Table 2 here]}

\subsection{Determinants of participation in the land rental market}

Summary statistics of the variables used in the analysis are presented in Table 3 . The average amount of cultivated land owned is 0.54 ha; the average highest level of education in the household is 6.9 years; experience in farming is 25.5 years; average family size is six persons; $22 \%$ of income is derived off-farm; and only $13 \%$ of farmers have had contact with 
extension services during the past year. The computed Herfindahl index of crop diversification ranges from 0.18 to 1.00 , with a mean score of 0.60 , indicating strong presence of diversification among enterprises; and $62 \%$ of the farm area is irrigated.

\section{[Insert Table 3 here]}

The result of the full information maximum likelihood estimation of the bivariate Tobit model is presented in Table 4. Prior to discussion of the findings we present the results of various model diagnostic tests reported in the lower panel of Table 4. Globally, $50 \%$ of the estimated coefficients were significantly different from zero, at $10 \%$ level at least indicating that inclusion of these variables were correctly justified in explaining the determinants of land transactions. The Wald $\chi^{2}$ test results further indicates statistically that these variables contribute significantly as a group to the explanation of the joint determinants of renting-in and renting-out land by the farmers. The key hypothesis of "correlation of the disturbance term between the two equations "per capita land rented-in" and "per capita land rentedout" is zero $\{$ i.e., $\rho$ (rented-in, rented-out $)=0\}$ " is strongly rejected at the $1 \%$ level of significance, implying that the use of a bivariate tobit model to determine farmers' decisions to participate in the land rental market is justified. This result also confirms that univariate analysis of such a decision making process will lead to biased results, which is a common practice in the literature. Also, both sigma values were significantly different from zero at the $1 \%$ level.

Apart from reporting model diagnostic results from the bivariate tobit model, we present some additional fit measures of the model based on univariate tobit models of rentingin land and renting-out land ${ }^{7}$. We report two fit measures, namely, the McFadden's $\mathrm{R}^{2}$ and

\footnotetext{
7 This is because the available softwares which allow bivariate tobit model to be estimated (i.e., LIMDEP 9 and/or STATA 10) do not provide any additional model diagnostic tests. However, STATA 10 reports a detailed set of model fit results for univariate tobit models. Our assumption in reporting these results is that if the tests
} 
McKelvey and Zavoina's $\mathrm{R}^{2}$. Overall, the fit seems to be relatively better for the rented-in land model compared with the rented-out land model. The typical value of McFadden's $\mathrm{R}^{2}$ lies between $0.20-0.40$ (Sonka et al., 1989) which is also seen in our results. The implication is that our full models are better than the intercept only models. Similarly, the square root of the McKelvey and Zavoina's $\mathrm{R}^{2}$ provides a measure of the correlation between the latent continuous variable and the predicted probabilities. Our results show that the strength of such correlation is 0.871 for the rented-in land model and 0.508 for the rented-out model, indicating strong predictability. Finally, we test for the key assumption of the normality of the residuals of a tobit model using the Conditional Moments Test $\left(\mathrm{H}_{0}\right.$ : Tobit residuals are normally distributed). We apply the method proposed by Drukker (2002) who recommended that the critical values for the test should be obtained via a parametric bootstrapping method after Tobit estimation (for details of testing procedure, see Drukker, 2002). We applied 1000 replications to obtain our critical values in order to essentially remove the classic criticism of size distortions arising from the standard conditional moments test after Tobit estimation. The test results confirm that the null hypothesis of the normality of Tobit residuals cannot be rejected, at the $1 \%$ level, for any of the models.

\section{[Insert Table 4 here]}

It is clear from Table 4 that a number of socio-economic factors (both land and non-land factors) affect farmers' participation in the land rental market but thse work in opposite directions regarding decision to rent-in or rent-out land, as anticipated. A total of eight variables have a significant relationship with the decision to rent-in land and another eight variables have a significant relationship with the decision to rent-out land. The likelihood of renting-in land is higher for farmers with inadequate owned cultivated land, as expected. Also, the likelihood of renting-in land is higher for farmers with higher levels of livestock and other farm 
capital assets. The implication is that those who are rich in non-land factors (e.g., livestock or farm capital assets) rent-in land, to optimise their farm sizes, in order to utilize their surplus resources, which corresponds with the findings of Kung (2002), Tikabo and Holden (2004), Holden et al., (2007), and Masterson, (2007) for farmers in China, Eritrea, Ethiopia, and Paraguay, respectively. Deininger and Jin (2005) also noted that, contrary to concerns that land rental markets may leave out the poor, market transactions did transfer land to those with lower initial endowments in China.

The exact opposite is true for farmers who rent-out land. We see that the endowment of cultivable land significantly influences the decision to rent-out land which also corresponds with the findings of Teklu and Lemi (2004). Also, farmers endowed with inadequate non-land factors (e.g., farm capital and livestock resources) are more likely to rent-out land, which corresponds with the findings of Tikabo and Holden (2004) and Holden et al., (2007).

The impact of education on the decision to rent-out and/or rent-in land is quite mixed in the literature. We see that the households with high levels of educated members (not necessarily the household head) are more likely to rent-out land, whilst the opposite is true for the households who rent-in land. The implication is that the opportunity to engage in nonfarm activities increases with education and, therefore, households rent-out land in order to substitute their time input away from agricultural production. This finding corresponds with Deininger et al., (2003), Teklu and Lemi (2004), and Swinnen et al., (2006) but is in contract with Tikabo and Holden (2004), Holden et al., (2007) and Masterson (2007). They noted that farmers' education either has a negative impact on land rented-out or a positive impact on land rented-in, implying imperfection in the market for human capital. On the other hand, Kung (2002) and Vranken and Swinnen (2006) noted that education significantly reduces the demand for rented-in land in China and Hungary, which is also observed in our study. Teklu and Lemi (2004) noted that an increase in the level of education tends to increase the 
opportunity cost of participating in farming, which we think is true for Bangladesh as well.

Farming experience, which is arguably a more direct measure of experience than age, but used by very few in the literature (e.g., Tikabo and Holden, 2004), seems to have no influence on the decision to rent-in or rent-out land, which is quite contrary to some of the findings in the literature which are, in turn, very mixed in their conclusions. For example, Kung (2002) and Vranken and Swinnen (2006) reported positive influence of age on renting-in land, while Deininger et al., (2003), Tikabo and Holden (2004), and Masterson (2007) reported a negative influence. On the other hand, Teklu and Lemi (2004), Swinnen et al., (2006) and Masterson (2007) reported a positive influence of age on renting-out land, while Deininger and Jin (2005) reported a negative influence.

The likelihood of renting-out land is higher among households with relatively less subsistence pressure (i.e., lower family size), which corresponds with the findings of Teklu and Lemi (2004). Kung (2002) reported that dependency ratio positively influence decision to rentin land.

Farmers with poor extension contacts are also more likely to rent-out land. This may be because farmers with lack of access to technological information and knowhow find it better to rent-out land and earn a fixed predetermined income rather than going through the uncertain production process.

The effect of non-agricultural income share is uni-directionally negative but is significant in the rented-out model, implying that farmers with a lower share of non-agricultural income tend to rent-out land to raise total household income. Kung (2002), however, noted that households with active participation in the off-farm labour market rent-in less land in China.

The effect of crop diversification and access to irrigation seem to have no influence on the likelihood to participate in the land market, whereas Tikabo and Holden (2004) found a positive influence of size of area irrigated on the decision to rent-in land and a negative 
influence on the decision to rent-out land in Eritrea.

Among the village level variables, the likelihood of renting-in land is higher in areas with developed infrastructure as well as fertile soils. This is because developed infrastructure eases the constraints on marketing of outputs, purchase of inputs, access to information and so forth. Therefore, farmers with initial lower land endowment are likely to rent-in land to optimise their farm size and reap the benefit of developed infrastructure. Ahmed and Hossain (1990) concluded that infrastructure has profound impacts on the income of the poor in Bangladesh, raising their income by $33 \%$, which is partially the result of a higher level of modern rice technology adoption that in turn increases the demand for cultivable land.

Our results show that farmers tend to rent-in land in fertile areas in order to reap the benefit of higher productivity of crops from soils of relatively high fertility status of the soils. Vranken and Swinnen (2006) used an indicator variable for land quality at county level measured in terms of monetary value, but found no influence of this variable on the decision to rent-in or rent-out land in Hungary.

Village level inequality seems to have no effect on the decision to participate in the land market, in contrast to Teklu and Lemi (2004) who observed that farmers in villages with initial high degrees of inequality transact more land through land rental markets in Ethiopia.

Geography does matter. The incidence of transacting land is significantly higher in the Comilla and Jamalpur regions, which is also reflected in Table 2. Both the Comilla and Jamalpur regions are relatively densely populated areas, with very low land ownership per capita as compared with Jessore. In fact, Jamalpur is the official agricultural production region of the country, while Comilla is conventionally an agriculturally developed region where most of the innovations were initiated, e.g. green revolution technology.

\section{Conclusions and policy implications}


The study explores the socio-economic determinants of the decision to participate in the agricultural land rental markets in rural Bangladesh, using a bivariate Tobit model. The results are discussed explicitly in light of the existing literature, to compare and contrast our findings. In addition a cognisant of the fact that each country is unique in its setting and therefore, should be studied separately, we would expect to see a certain level of robustness of results across studies.

Our approach also allows for greater flexibility as it enables us to examine both the demand side as well as the supply side factors of land market transactions jointly. The model diagnostics have confirmed jointness of the decision to rent-in and/or rent-out land, thereby, justifying our use of the bivariate approach.

The results reveal that a number of socio-economic factors affect farmers' participation in the land rental market but work in opposite directions regarding decisions to rent-in or rentout land. The hypothesis that resource rich but land poor farmers tend to rent-in land, while land rich but resource poor farmers tend to rent-out land has been validated in our study. The broader implication of this finding is that these land rental markets go a long way to equalising the unbalanced factor proportions of individual farmers, and are broadly in line with the findings of the existing literature. Apart from land and non-land productive resources, other socio-economic and regional level factors play an important role in farmers' decisions to engage with the land rental markets. For example, education seemingly enables households to engage in non-farm activities and, therefore, educated households tend to rent-out land, while households with less education opt to rent-in land. In addition, poor extension contact, less subsistence pressure and lower shares of non-agricultural income induces households to rent-out land.

Government policy has an important role to play to improve the factor equalisation role of these land rental markets because farming is still dominant as an important source of livelihood in Bangladesh. However, the conventional land reform measure to equalise land 
ownership amongst farmers, which is a common policy suggestion in land scarce economies, is not feasible in the case of Bangladesh because of the technical and economic limitations, as well as political economy, of its agrarian structure. For example, Rahman and Rahman (2009) noted that the compulsory redistribution of land from large farmers to marginal and landless farmers (probably impossible to implement) would leave each landless household with only 0.21 ha of land, which is unviable as a livelihood resource. Furthermore, land is only one of the key essential factors required in order to sustain livelihoods from farming. Other key factors (e.g., livestock resources and farm capital assets) which are also unequally distributed among the farming population are essential in farming too. Therefore, the key policy thrust will be to facilitate operation of the land rental markets, as well as to improve ownership of the non-land resources that are also essential in farm operations. Our results clearly demonstrate that a sensible approach, therefore, would be to invest in education (targeted to farm households), agricultural extension services, rural infrastructures, as well as the livestock sector. All these investment areas also have a synergistic role in improving production efficiency of Bangladeshi farmers (Rahman and Rahman, 2009 and Rahman and Hasan, 2008) which, in turn, would improve the overall livelihoods of these farm households. 


\section{References}

Ahmed, R., Hossain, M. 1990. Developmental impact of rural infrastructure in Bangladesh. IFPRI Research Report 83. International Food Policy Research Institute, Washington, D.C.

Akanda, M.A.I., Isoda, H., Ito, S. 2008. Problem of share-cropping system in rice farming $\mathrm{n}$ Bangladesh: a case study on Alinapara village in Sherpur district. Journal of International Farm Management, 4: 1-13.

Arkin, H., Colton, R.R., 1963. Tables for Statisticians. $2^{\text {nd }}$ Edition. Harper and Row Publishers, New York.

BBS, 1999. Census of Agriculture, 1996: Structure of Agricultural Holdings and Livestock Population, National Series, Volume 1. Bangladesh Bureau of Statistics, Dhaka. Bangladesh.

BBS, 2009. Census of Agriculture, 2008: Preliminary Report. Bangladesh Bureau of Statistics, Dhaka. Bangladesh.

Bell, S., Sussangkarn, C., 1988. Rationing and adjustment in the market for tenancies: the behaviour of landowning households in Thanjavur district. American Journal of Agricultural Economics, 70: 779-89.

Bradshaw, B. 2004. Questioning Crop Diversification as a Response to Agricultural Deregulation in Saskatchewan, Canada. Journal of Rural Studies, 20, 35-48.

Deininger, K. Jin, S. 2005. The potential of land rental markets in the process of economic development: evidence from China. Journal of Development Economics, 78: 241-270.

Deininger, K., Zegara, E., Lavadenz, I. 2003. Determinants and impacts of rural land market activity: evidence from Nicaragua. World Development, 31: 1385-1404.

Drukker, D.M. 2002. Bootstrapping a conditional moments test for normality after tobit estimation. Stata Journal 2, 125-139. 
FAO, 2001. Supplements to the Report on the 1990 World Census of Agriculture. Statistical Department Series (9a). Food and Agriculture Organisation, Rome. http://www.fao.org/es/ess/census/wcahome.htm

Holden, S.T., Deininger, K. Hosaena, G. 2007. Impact of land certification on land rental market participation in Tigray Region, Northern Ethiopia. MPRA (Munich Personal RePec Archive) Paper No. 5211, Germany. Available online at http://mpra.ub.unimuenchen.de/5211/.

Kung, J.K. 2002. Off-farm labour markets and the emergence of land rental markets in rural China. Journal of Comparative Economics, 30: 395-414.

Llewelyn, R.V., Williams, J.R., 1996. Nonparametric analysis of technical, pure technical, and scale efficiencies for food crop production in East java, Indonesia. Agricultural Economics, 15: 113-126.

Masterson, T. 2007. Land rental and sales market in Paraguay. The Levy Economics Institute Working paper \# 491. Bird College, New York.

McDonald, J.F.; Moffit, R.A. 1980. The uses of tobit analysis. Review of Economics and Statistics, 61: $318-321$.

Niroula, G.S., Thapa, G.B. 2005. Impacts and causes of land fragmentation, and lessons learned from land consolidation in South Asia. Land Use Policy, 22: 358-372.

Rahman, 2009. Whether crop diversification is a desired strategy for agricultural growth in Bangladesh? Food Policy, 34, 340-349.

Rahman, S. 1998. Socio-economic and environmental impacts of technological change in Bangladesh agriculture. Unpublished Ph.D. thesis. Asian Institute of Technology, Bangkok, Thailand.

Rahman, S. and Hasan, M.K. 2008. "Impact of environmental production conditions on productivity and efficiency: a case study of wheat farmers in Bangladesh”. Journal of 
Environmental Management 88: 1495-1504.

Rahman, S., Parkinson, R.J. 2007. "Soil fertility and productivity relationships in rice production system, Bangladesh. Agricultural Systems. 92: 318-333.

Rahman, S., Rahman, M.M. 2009. Impact of land fragmentation and resource ownership on productivity and efficiency: the case of rice producers in Bangladesh. Land Use Policy, 26, 95-103.

Sonka, S.T., Hornbaker, R.H., Hudson, M.A., 1989. "Managerial Performance and Income Variability for a Sample of Illinois Cash Grain Producers". North Central Journal of Agricultural Economics 11: 101-118.

SRDI. 1991. Soil Guides for Crop Production, 1991 (in Bangla.) Soil Resource Development Institute, Dhaka.

STATA Corp, 2007. STATA Version 10. Stata Press Publications, College Station, Texas, USA.

Swinnen, J., Vranken, L, Stanley, V. 2006. Emerging challenges of land rental markets: a review of available evidence for the Europe and Central Asia region. Chief Economist's Working Paper Series, Vol. 1, No. 4. The World Bank, Washington, D.C.

Tikabo, M.O., Holden, S.T., 2004. Factor market imperfections and the land rental market in the Highlands of Eritrea: theory and evidence'. Paper presented at the CSAE Conference 2004 on 'Growth, poverty reduction and human development in Africa'. Available online at http://www.csae.ox.ac.uk/conferences/2004-GPRaHDiA/ papers/ 2a-Tikabo-CSAE2004.pdf

Vranken, L., Swinnen, J. 2006. Land rental markets in transition: theory and evidence from Hungary. World Development, 34: 481-500. 


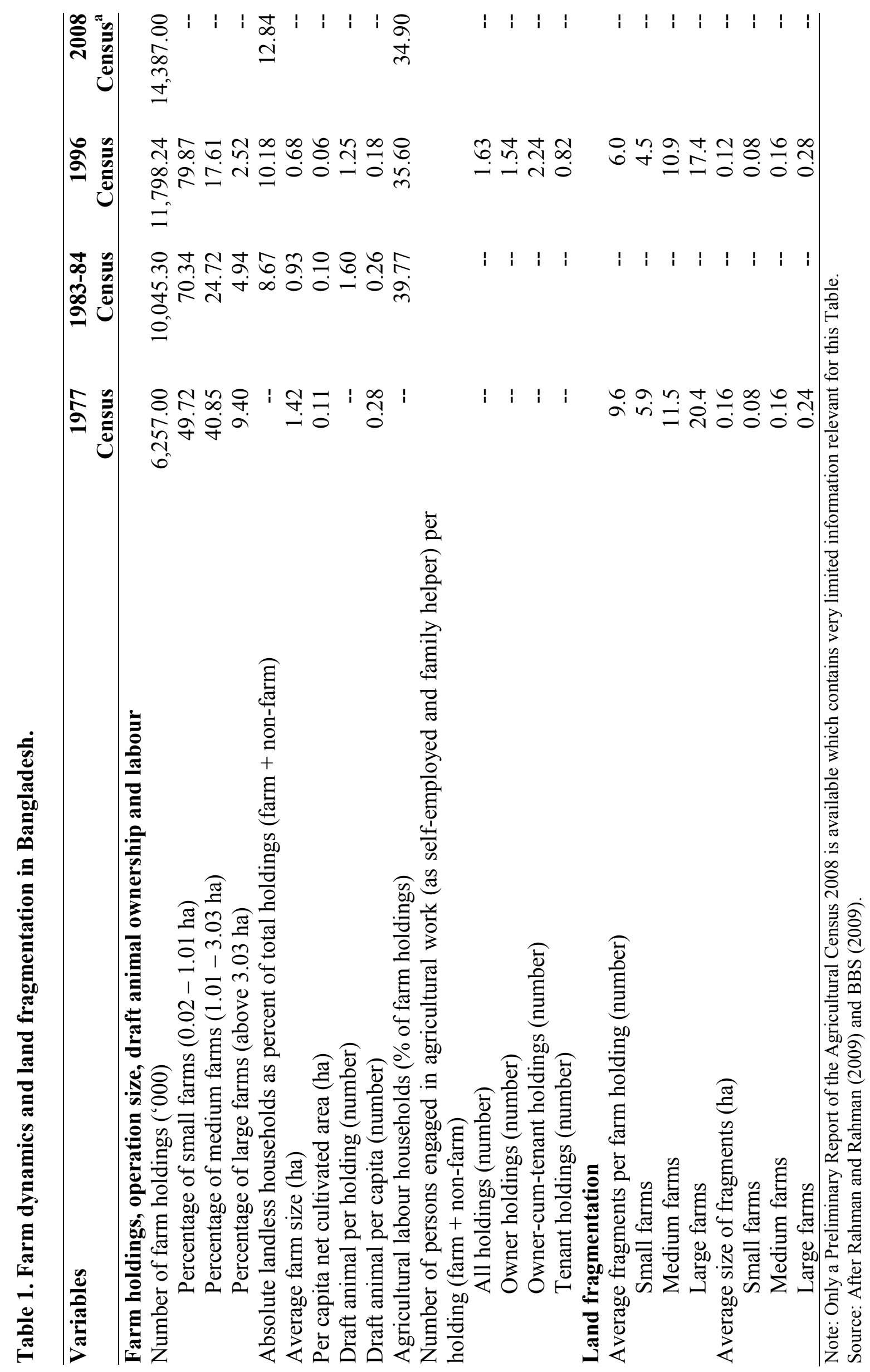




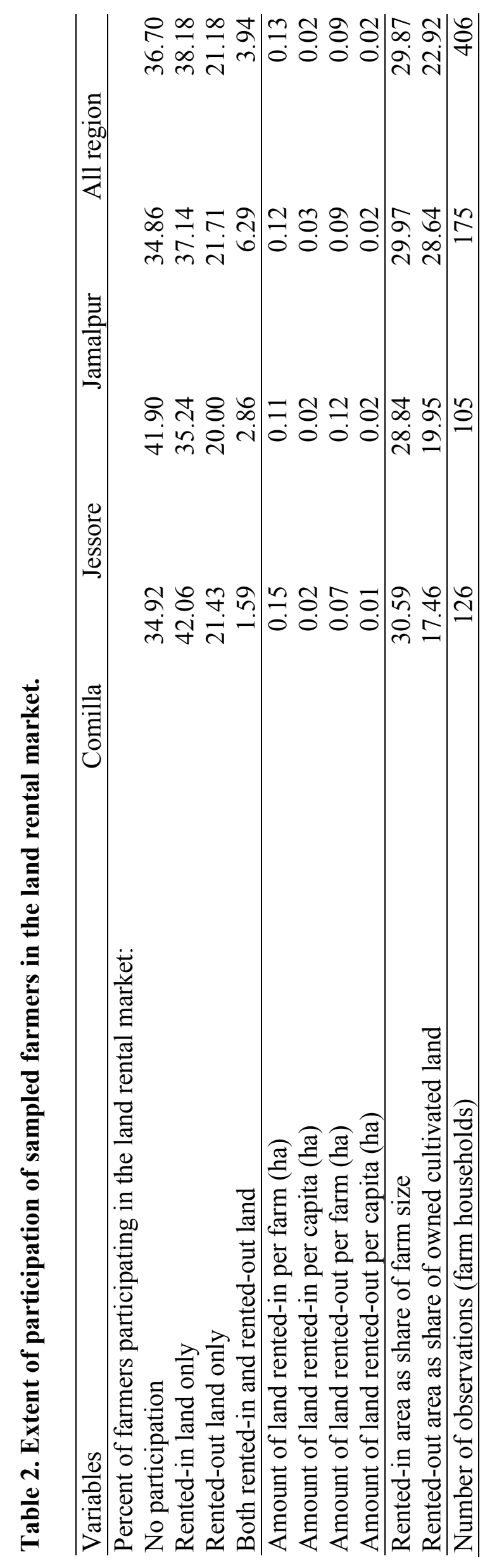




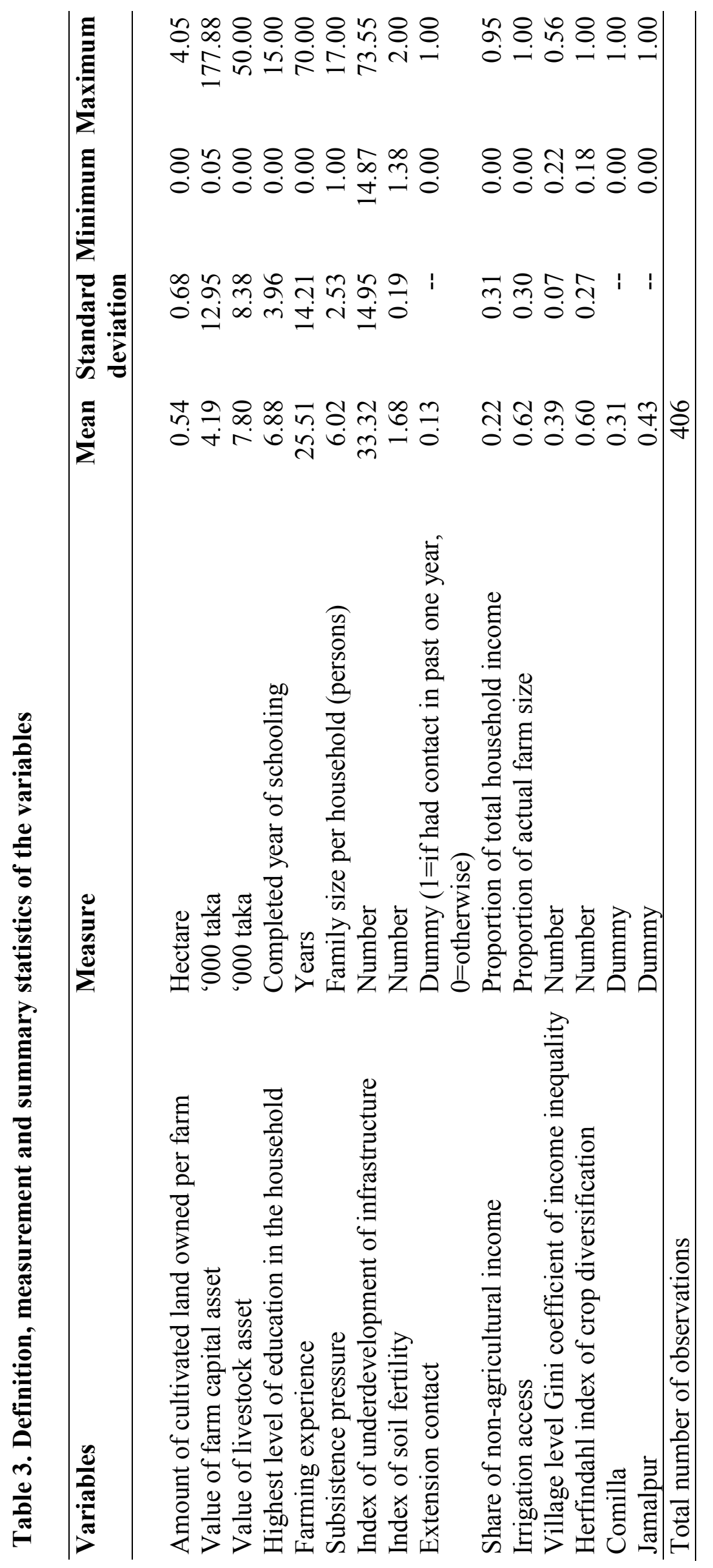




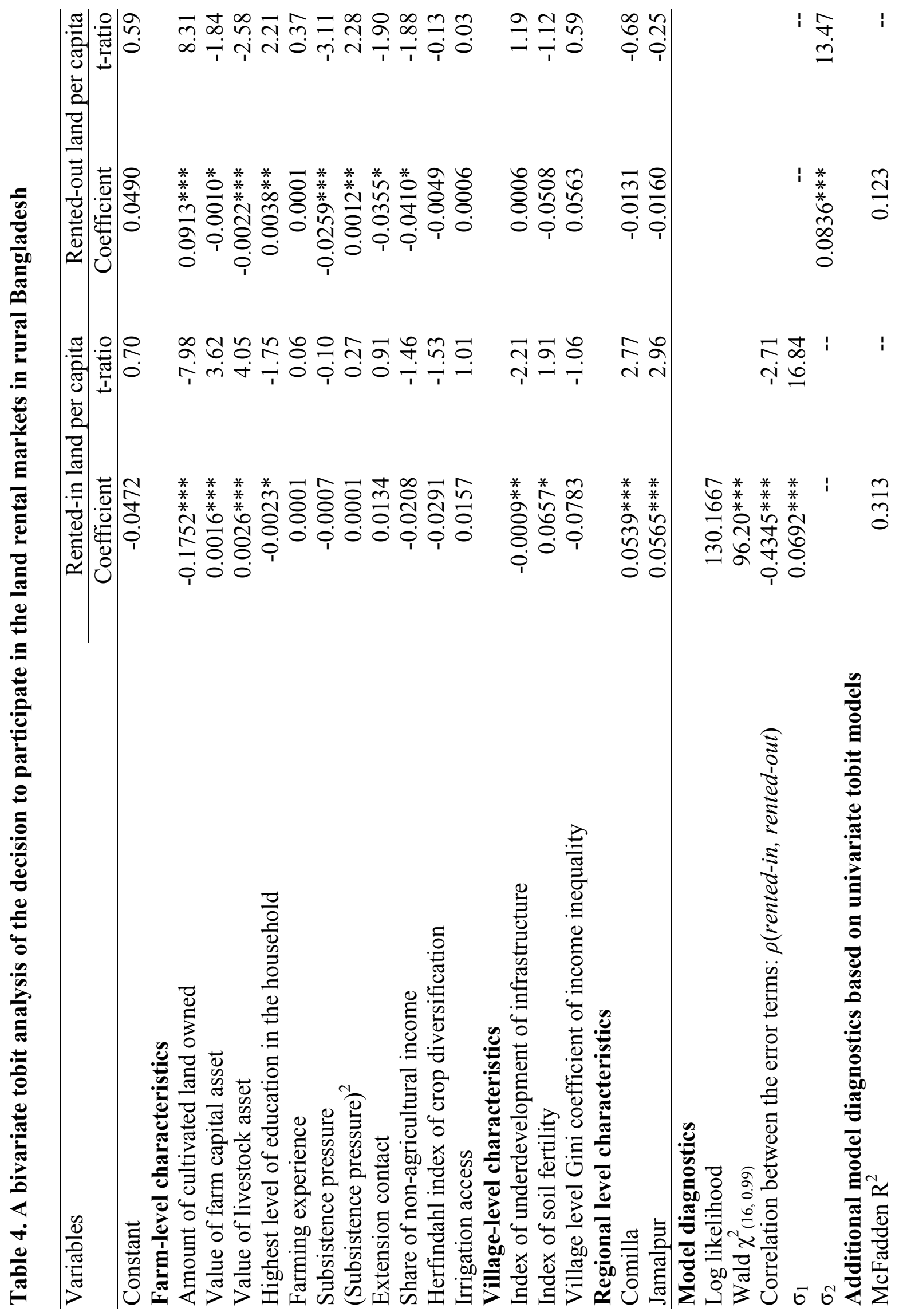

$\stackrel{\llcorner}{\sim}$ 


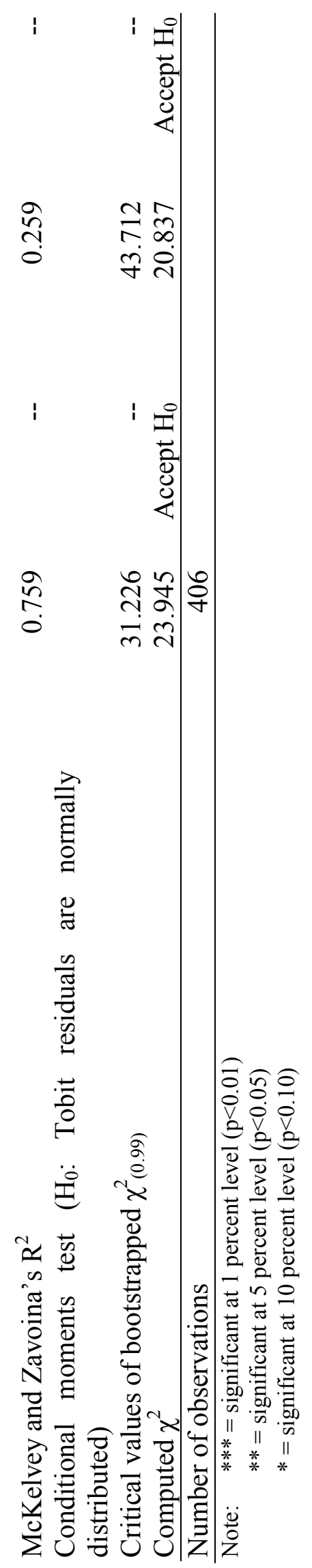

